SOBRE O QUE SE

QUIS CALAR:

\section{o tráfico de africanos no litoral norte de São Paulo em tempos de pirataria}

What was Meant to be Silent: The African Slave Trade on

The North Coast of São Paulo in Times of Piracy
Thiago Campos

\section{PESSOA}

(D) tcpessoa@hotmail.com

Universidade

Federal Fluminense

Niterói, RJ, Brasil

\section{RESUMO}

No texto que segue, analisaremos a reorganização do comércio de africanos na clandestinidade tendo como escopo o litoral norte de São Paulo entre 1831 e meados da década de 1850. Nesse período, fazendas, sítios e barracões foram montados nas praias de Ubatuba, São Sebastião e llhabela com parte da nova logística do tráfico de africanos na clandestinidade. Para muito além de produção de subsistência e do comércio de cabotagem, aquelas praias foram intensamente marcadas pelos últimos anos do tráfico atlântico de escravizados.

Palavras-chave: Comércio de africanos, Tráfico ilegal de escravizados, Província de São Paulo.

\begin{abstract}
In the following text, we will analyze the reorganization of the illegal slave trade, having as scope the northern coast of São Paulo between 1831 and the mid-1850s. In that period, farms, sites and sheds were built in the beaches of Ubatuba, São Sebastião and Ilhabela as part of the new logistics of the illegal slave trade. Far beyond the subsistence production and the cabotage trade, those beaches have been intensely marked by the last years of the Atlantic slave trade.
\end{abstract}

Keywords: African slave trade, illegal slave trade; São Paulo Province. 


\section{O litoral norte de São Paulo e o tráfico de africanos na clandestinidade}

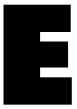
ntre 1938 e 1945, Felix Guisard Filho (1890-1964), médico e pesquisador do Vale do Paraíba, publicou ampla documentação de natureza política sobre a história dos municípios cafeeiros, com destaque para Taubaté. Em dez volumes transcreveu todos as atas daquela Câmara em cerca de 100 anos de funcionamento, cobrindo o período de 1780 a 1890 (GUISARD FILHO, 1943-1944, 10 v.). Como quem conhecia profundamente o Vale, considerava o litoral que o margeava parte do complexo que buscava dar visibilidade. Talvez, por isso, dedicara uma de suas obras a história de Ubatuba, construindo sua narrativa na longa duração (GUISARD FILHO, 1940). Nela, o médico-pesquisador deixava evidente seu objetivo quase missionário: “(...) divulgar os documentos, oferecê-los ao exame dos investigadores e estudiosos, antes que as traças e a negligência dos homens tenham conseguido levar a cabo a sua faina destruidora" (GUISARD FILHO, 1940, p. 38).

Em suas Achegas à história do litoral paulista, no curto capítulo IV - "O Negro e - Vale do Paraíba" - Guisard Filho questionava-se sobre o "aumento vertiginoso" da população africana e de seus descendentes no litoral norte paulista. Para o autor, a explosão demográfica da escravidão naquele espaço não estava "suficientemente explicada com os mercados de escravos do Rio de Janeiro". Tampouco via o porto de Santos como responsável exclusivo por receber os africanos na clandestinidade. Acreditava que por ali "fossem diminutas as chegadas da mercadoria africana, levandose em conta o fato de ser um porto já bem frequentado e, portanto, vigiado pelos da terra, como pelos cruzadores ingleses" (GUISARD FILHO, 1940, p. 187). Exímio conhecedor da documentação do Vale, sugestionou que o litoral norte paulista - muito além das praias de Santos - era o espaço de recepção e redistribuição dos africanos que não paravam de chegar nas lavouras cafeeiras de serra acima.

A questão despachada por Guisard Filho não se converteu em agenda de investigação da historiografia dedicada ao tráfico negreiro (PEREIRA; PESSOA, 2019). Ao revés, o litoral norte da antiga província de São Paulo por anos figurou como espaço menor na análise da escravidão no oitocentos, em contraponto a sua explosão demográfica e concentração em municípios cafeeiros como Rio Claro, Bananal e Campinas (DEAN, 1977; MOTTA, 1999; MORENO, 2013; SLENES, 1999). Análises seminais, reiteradas em pesquisas posteriores, entenderam àquele espaço como áreas de domínio dos caiçaras, com forte vínculo com o setor de abastecimento, resultando em uma demografia típica de áreas empobrecidas, com acesso limitado à propriedade escrava, marcada pelo protagonismo de pescadores e camponeses (MARCÍLIO, 1986). Se as análises demográficas em muito contribuíram para construção de um panorama socioeconômico do litoral norte de São Paulo, em parte eclipsaram o envolvimento dos seus municípios ao comércio atlântico de africanos em sua fase ilegal. Atualmente trabalhos na interface entre arqueologia e história oral evidenciam as reminiscências do cativeiro ilegal naquelas praias, seja por meio da análise da cultura material (AGOSTINI, 2011) ${ }^{1}$ ou do acionamento da memória da escravidão, sobretudo, nas comunidades remanescentes de quilombo (ALVES, 2016). 
De maneira mais direta, o silêncio imposto como política de Estado ao comércio ilegal de africanos (MAMIGONIAN, 2017) e o amplo apoio social que despertava entre aqueles que dele dependiam (CARVALHO, 2012), fez ocultar personagens, espaços e estruturas do crime de reduzir homens, mulheres e muitas crianças livres ao cativeiro no Brasil. Segundo os dados compilados pelo projeto The Transatlantic Slave Trade Database - Voyages, 81 viagens negreiras foram registradas para o litoral paulista na era da clandestinidade. Entre 1836 e 1850, de Cananéia a Ubatuba, totaliza-se o envio de pouco mais de 43 mil africanos. Vejamos na tabela a seguir:

Tabela 1 - Tráfico de africanos para o litoral de São Paulo (1836-1850)

\begin{tabular}{lcccc}
\hline Municípios & Períodos & Viagens & Embarques & Desembarques \\
\hline Cananéia & 1839 & 1 & 662 & 600 \\
Santos & $1837 ; 1841-44 ; 1850$ & 14 & 8.692 & 7.317 \\
São Sebastião & $1834-45 ; 1850$ & 64 & 31.838 & 28.405 \\
Ubatuba & $1836-1837$ & 2 & 1.855 & 1.679 \\
Total & - & 81 & 43.047 & 38.001 \\
\hline
\end{tabular}

Fonte: <https://www.slavevoyages.org/>. Acesso: marco de 2019.

Nos dados compilados, o litoral de São Paulo recebeu cerca de $10 \%$ das viagens negreiras e dos africanos desembarcados no Sudeste a partir de 1831. ${ }^{2}$ Embora apenas referencial, o percentual ilustra a importância das praias paulistanas na finalização do comércio negreiro em escala atlântica. A descontinuidade e imprecisão dos números são produtos da própria exposição pública dos desembarques e da capacidade de repressão das forças britânicas e brasileiras no contexto em que a o tráfico fora equiparado a pirataria e a lei de 1831 ainda não era letra morta (BETHELL, 2002; MAMIGONIAM, 2017).

Nesse sentido, duvidamos que tenha havido apenas um desembarque em Cananéia durante 20 anos; ou que nenhum tenha ocorrido em Santos nos últimos três anos da década de 1830. De igual modo que São Sebastião e Santos não tenham recebido sequer um navio negreiro na segunda metade da década seguinte, quinquênio conhecido como o auge do comércio negreiro em quase 300 anos de história. Em relação à Ubatuba, a subnotação, também evidente, vincula-se ao seu caráter jurisdicional, fronteiriço à São Sebastião, dificultando a delimitação entre os dois municípios, ao que parece, espaços privilegiados no crime de reduzir pessoas juridicamente livres à escravidão. Por isso, como veremos, muitos desembarques atribuídos à São Sebastião, ocorreram, na verdade, nas proximidades da antiga vila de Ubatuba, correspondente, atualmente ao município de mesmo nome. De igual maneira, em relação à Caraguatatuba, freguesia elevada à município somente em 1857.

No entanto, por que a despeito dos silêncios característicos das situações de clandestinidade, São Sebastião - aqui considerado de maneira ampliada, englobando Ubatuba e Caraguatatuba - concentrou de maneira quase exclusiva cerca de $75 \%$ dos 
38 mil africanos desembarcados no litoral paulista? Muitos fatores podem ter contribuído para o protagonismo daquelas praias. Talvez, o compromisso das autoridades locais e dos caiçaras com a reestruturação do tráfico, ou ainda, condições ideais para atracagem e desembarque dos recém chegados expliquem a concentração em São Sebastião. Embora não possamos ser assertivos nas respostas, procuraremos mostrar como suas praias foram, desde muito cedo, montadas para a finalização dos empreendimentos atlânticos. Lá estavam alguns dos novos portos negreiros, interligados a ranchos e fazendas, que fariam funcionar a estrutura traficante existente na clandestinidade ao longo de grande parte do litoral brasileiro. Negociantes, fazendeiros e caiçaras agiam em conjunto a fim de reerguer e sustentar a pirataria e o roubo a liberdade de milhares africanos por quase duas décadas (RODRIGUES, 2005; FERREIRA, 2012; PEREIRA. 2011; PEREIRA 2018; PEREIRA; PESSOA, 2019).

\section{Fazendas-negreiras e o reerguimento do tráfico nos anos de $\mathbf{1 8 3 0}$}

Em ofício de 28 de Junho de 1833, Rafael Tobias d'Aguiar, então presidente da província de São Paulo, questionava Francisco Lourenço de Freitas, juiz de direito da $6^{a}$ comarca, sobre as fortes suspeitas de um grande desembarque de africanos na praia de Tabatinga. No ofício, Aguiar solicitava informações exatas dos introdutores e compradores dos ditos "pretos novos" que teriam sidos rapidamente vendidos a "lavradores de serra acima" e moradores do distrito. Depois de algumas missivas, em 03 de agosto daquele ano, Lourenço de Freitas prestava conta do que dizia saber:

Logo que recebi o ofício de $V$ Exa. de junho deste ano, em que me ordenou de informar relativamente a introdutores e compradores de pretos novos, sobre que há veemente suspeitas de serem desembarcados em número de 600 na fazenda Tabatinga do Capitão José Martins, passei imediatamente com meu escrivão aquele lugar, distante desta Vila sete léguas e como não achasse vestígios do que fazia objeto da minha condução, pois que só achei duas negras do referido Martins que perguntando-lhes, responderam-me nada saberem. Seguia adiante uma légua, a fazenda de Maranduba do francês Agostinho Stevenin, de quem obtendo respostas no mesmo sentido, deliberei oficiar as pessoas de melhor conceito, cujas respostas são as que incluso remeti a V. Exa. Sobre conduta dos Juízes de Paz, tenho de responder a $V$ Exa. que não me consta tenham deixado de cumprir seus deveres relativamente a introdução de pretos novos, pois que não me consta nem por denúncia ou [pasquins], e nem por conversas a este respeito, que se tenha efetuado tal desembarque, e por consequência um tal tráfico desumano $(. . .)^{3}$

A resposta do juízo é típica das autoridades de repressão ao tráfico antes da lei Eusebio: dizem nada saberem. Nesse caso, Lourenço poderia realmente desconhecer o caso, haja vista a novidade dos desembarques na região. Mais provável, no entanto, que seus compromissos políticos o fizessem calar. Um mês antes daquele ofício, e menos de uma semana depois de ser questionado pela presidência da província, já informava: "não me consta houvesse compradores de semelhantes pretos de 
lavradores deste distrito e muito menos de serra acima". ${ }^{4}$ Há tentativa deliberada de se ocultar os agentes do crime, e distanciar quaisquer vínculos entre os desembarques e a elite do café estabelecida "serra acima", mas com efetivos negócios nas franjas do mar que recebiam os últimos desembarques de africanos do Império. Outro aspecto em destaque é a cobrança da presidência da província em relação aos juízes de paz, àquela altura ainda com poderes de polícia e principais responsáveis pela repressão às ilicitudes em suas freguesias. O comprometimento dessas figuras com o comércio negreiro não era novidade para as autoridades do Império nos anos de 1830. O famoso Alcoforado afirmara que mesmo na Corte era costumeiro o suborno aos funcionários de fiscalização portuária, ou aqueles responsáveis pelo controle e emissão de passaportes (FERREIRA, 1995).

Em 17 de março do ano seguinte, em depoimento ao diligente José Antonio Pimenta Bueno, que àquela altura acumulava o cargo de chefe de polícia da província e juiz da comarca, o capitão-mor de Vila Bela da Princesa, no sossego de seu sítio praieiro, avistara um barco de 3 mastros se aproximar da terra pelo lado da contra costa da llha Bela. Antes que fosse encontrado, o navio fez-se vela em direção à llha dos Búzios. Segundo o capitão-sitiante, o que via parecia coadunar com o que, a pouco, ouvira: um tal Sebastião, genro de outro capitão-mor, esse autoridade do Governo Geral de Angola, era esperado com embarcação apinhada de cativos.

Cerca de 15 dias depois, em novo ofício, Pimenta Bueno agregava novos detalhes ao caso. Afirmava que havia pouco dias o navio visto ao largo daquelas praias realizara perto de Castelhanos, "na dita contra costa, um desembarque de grande número de africanos (...) e dali se passaram imediatamente em canoas de voga para terra firme ao lado do Bananal e talvez ora já estejam em cima da serra". ${ }^{5} \mathrm{Na}$ mesma missiva, o chefe de polícia alertava que já era esperada a vinda de outro negreiro, com chegada próximo àqueles dias.

As denúncias e a insistência do futuro Marques de São Vicente parecem evidenciar que o litoral norte paulista, entre Ubatuba e São Sebastião, passava a se destacar no reerguimento do tráfico na clandestinidade, confirmando o que os próprios números do comércio negreiro apontam. Ao que parece, aquelas praias serviam como novas bases de atracagem dos tumbeiros que já chegavam um ano após a aprovação da lei de 07 de novembro 1831. Em correspondência com a Presidência da Província, Pimenta Bueno dava conta das diligências realizadas contra "criminosa importação e comércio de africanos nas vilas de Ubatuba, São Sebastião e Bela da Princesa”. Com certa carga de frustração, no contexto do desembarque ocorrido em Castelhanos em março de 1834, afirmava:

Poucas esperanças concebi de que os miseráveis pretos fossem restituídos a liberdade que a natureza, a moral, a religião e a lei santamente reclamam, logo que conheci que aquele infame tráfico começou já desde 1832, que a importação excedia muito mais de 2 mil africanos, que mais avultado era número das pessoas incursas em semelhante crime. Todavia algumas esperanças ainda me restavam se não em relação a totalidade 
das vítimas, ao menos relativamente a uma parte delas, a vista das seguintes considerações:

Os três principais pontos de desembarque e venda dos africanos são fazendas pertencentes ao Distrito de Ubatuba e o juiz de paz (...) se havia constituído protetor da imoralidade. Os proprietários daquelas fazendas de Tabatinga, Saco das Bananas e Lagoinha, onde ainda existam escondidos muitos africanos, não podiam esperar a busca, senão pela ordem, e com aviso anterior do dito juiz de paz de Ubatuba (...) (Grifos meus). ${ }^{6}$

Impressiona o pioneirismo e o volume do comércio negreiro para aquelas praias. Segundo Pimenta Bueno, já em 1832 a importação se articulava com força, superando, em muito, os números não captados pelo projeto The Transatlantic Slave Trade Database - Voyages. Construídos basicamente a partir dos registros da repressão inglesa, os dados compilados em Voyages não captaram um desembarque sequer para àquele litoral antes de 1834, quando em maio daquele ano arribou o patacho Dois de Março em uma das praias de São Sebastião, procedente de Luanda. Ubatuba e Santos só figuram naqueles registos, em 1836 e 1837, respectivamente. O alerta do chefe de polícia serve como lembrança de que contamos apenas com uma aproximação imperfeita do volume e do que significou o comércio atlântico de seres humanos em sua fase clandestina. Ao mesmo tempo, evidencia o quão rápido foi a rearticulação do comércio negreiro na ilegalidade, meses após ser considerado pirataria pelos ingleses e proibido pelo parlamento brasileiro.

Nesse processo eram gradualmente montados portos e mercados de escravos por boa parte do litoral brasileiro. Com eles, erguia-se uma nova logística que ia do preparativo dos desembarques à redistribuição dos africanos, passando por sua recuperação e modulação à nova vida nas plantations. Em sítios, ranchos e fazendas constituídas à beira mar, surgiam esses espaços responsáveis pela intercessão entre o Atlântico e o cativeiro serra acima. Assim, o fechamento e a desarticulação da estrutura do Valongo, que concentrara os desembarques e a redistribuição dos africanos no centro-sul do Brasil do final do século XVIII a 1830, fora rapidamente substituída e pulverizada em Valongos menores, estruturados nas enseadas e praias do litoral norte paulista muito antes do que pensávamos. ${ }^{7} \mathrm{O}$ alerta do diligente Pimenta Bueno denota que a partir de 1832 determinadas praias do litoral norte paulista já haviam se convertido em portos negreiros. Como afirmara: "As providencias que se tem [dado] algum atinado na província do Rio, hão feito com que os belos e mansos ancoradouros destas costas sejam os portos do desembarque [de africanos]". ${ }^{8}$

Nos embates travados por José Antônio Pimenta Bueno transparecem partes dessas novas estruturas, como ancoradouros, fazendas, sítios e ranchos negreiros, além de pessoal de apoio, marujos recrutados naquele litoral para garantir a segurança necessária a finalização do empreendimento negreiro. Na penumbra desses agentes que na ponta operavam a finalização do empreendimento traficante, por vezes, apareciam outros sujeitos que compunham engrenagem muito maior: 
Dizem-me, e creio que uma sociedade é quem tem agitado este comércio sobre aquela costa, que além dos desembarques já feitos espera-se pelos barcos de que são mestres um estrangeiro de nome Jaques, e um Sebastião, genro do Cap. mor de Angola; e as costas que dão ótimos desembarques em todos os lugares constantes da tabela n ${ }^{\circ} 35$ não podem ser guardados se não por um cruzeiro efetivo. Esta é a providência única em que se deve confiar uma vez que o respectivo comandante seja homem de verdadeira probidade. ${ }^{9}$

Embora lacônico sobre os sujeitos que compunham tal sociedade, Pimenta Bueno fora mais direto ao identificar os novos espaços onde se articulava o reerguimento do tráfico na clandestinidade. A tal tabela n. 35, como veremos a seguir, era na verdade um ofício que resumia os possíveis pontos de desembarque daquele litoral.

\section{Cópia N.35.}

Os barcos podem fundear no distrito de Vila Bela em: $1^{\circ}$ Sombrio $-2^{\circ}$ Castelhanos $-3^{\circ}$ Estação $-4^{\circ}$ Serraria $-5^{\circ}$ Poço $-6^{\circ}$ Fome $-7^{\circ}$ Jabaquara $-8^{\circ}$ Saco dos Antonios - $9^{\circ}$ Pacuíba $10^{\circ}$ armação - $11^{\circ}$ todo o canal da llha.

Ditos podem fundear na costa de S. Sebastião e Ubatuba:

$1^{\circ}$ até o bairro desde a Vila $-2^{\circ}$ Caraguatatuba $-3^{\circ}$ Tabatinga $4^{\circ}$ Saco das Bananas $-5^{\circ}$ Lagoinha $-6^{\circ}$ dali por diante quase todos os lugares.

Nos lugares menos favoráveis as embarcações atravessam e vão as canoas de voga buscar os pretos. ${ }^{10}$

Em 12 de maio de 1837, Antônio Paulino Limpo de Abreu, à época Ministro das Relações Exteriores, transmitia à Presidência de Província de São Paulo nota remetida pelo ministro plenipotenciário de S.M. Britânica, com a relação dos navios entrados em lastro no porto do Rio de Janeiro nos primeiros meses daquele ano. Todos ocultavam-se em bandeira portuguesa e haviam desembarcado carga humana no litoral paulista. Limpo de Abreu cobrava informações sobre a questão e pedia que fossem reiteradas as ordens para se executar as leis vigentes no Império. Ao todo, tratava-se de quatro desembarques com o impressionante número de quase duas mil pessoas, como detalharam as autoridades inglesas. ${ }^{11}$

As investigações, iniciadas no segundo semestre de 1837, concentraram-se nos casos do Patacho Liberal e da Barca Comodoro e foram conduzidas pelo juiz de direito Joaquim Firmino Pereira Jorge. Para as autoridades locais nenhum desembarque havia ocorrido no ano de 1837, haja vista que os nove inspetores de quarteirão da vila de São Sebastião não ouviram nem rumores nesse sentido. Tampouco os caiçaras fizeram denúncia de tráfico na região. Caberia a Pereira Jorge quebrar o pacto de silêncio instaurando "processo informatório" para dar carga à portaria da presidência da província. A partir de 26 de agosto dera início aos interrogatórios, entre os muitos que já havia encaminhado. Findado os interrogatórios, o juiz do caso resumia o que concluíra sobre a matéria: 
(...) Processei testemunhas em diferentes classes, para ver se por esse modo descobria a verdade e só pude obter o que consta de alguns depoimentos, isto é, que não tinham notícia dos desembarques em questão e que os pontos em que lhes constava ter-se possíveis desembarcado africanos, pertencem ao município da vila de Ubatuba e não ao de São Sebastião, tais são os lugares denominados - Tamandoá, Lagoa, Lagoinha e Saco das Bananas.

Com efeito, eu creio, que são estes os pontos em que mais frequentemente se comercia em carne humana (...) E creio tanto mais, porque sou informado de que nesses lugares, ou em alguns deles, existem com escândalo ranchos e tarimbas só destinados ao inumano tráfico (...) É o que com toda a franqueza tenho a dizer, dando conta da comissão de que fui incumbido" (Grifos meus). ${ }^{12}$

A conclusão do juiz de direito faz ver os lugares especializados no desembarque de africanos no litoral norte de São Paulo, com ranchos à espera dos africanos. De alguma maneira nos leva também ao início do texto, quando referenciamos uma concentração bastante significativa de desembarques em São Sebastião. Como supúnhamos, parte deles se deram em Ubatuba, mas foram registrados pela repressão inglesa como destinatários à São Sebastião. O espaço de jurisdição onde ocorriam os desembarques confundiam até mesmo as autoridades brasileiras. No entanto, não havia dúvidas de que o mar entre Ubatuba e São Sebastião era o destino certo de muitos tumbeiros que partiam da África.

Como veremos, muitas dessas praias situam-se no epicentro das denúncias de desembarque negreiro na região em destaque. Do início dos anos de 1830 até meados de 1850 esses, espaços serviram como palco dos crimes perpetrados por contrabandistas de várias estirpes: negociantes, fazendeiros, autoridades locais e caiçaras. Em algumas dessas praias havia sítios e fazendas com significativo nível de especialização no ofício de transformar indivíduos juridicamente livres em solo brasileiro em cativos.

\section{As incursões de 1834, 1838 e 1840: as novas feitorias do tráfico desveladas}

Em março de 1834, após um dos negreiros que acabaram de desembarcar na região seguir a Castelhanos para "limpeza" dos vestígios do tráfico, iniciava-se processo de formação do sumário de culpa que previra incursão naquelas propriedades, obviamente sem a participação das autoridades do distrito de Ubatuba, "residência dos criminosos e lugar do delito". Recomendava-se junta policial, com força de 14 soldados que partindo de Santos deveriam atracar na vila de São Sebastião, para, então, à noite, zarparem rumo as fazendas e sítios que acoitavam os africanos. Lá deveriam amanhecer pois nelas "ainda se acham grande número de escravos, como é voz púbica”. A medida de busca e apreensão se fazia necessária justamente pelo silêncio tacitamente costurado em Ubatuba. Para o chefe de polícia, somente a investigação não seria suficiente para superá-lo: 
De dia a dia me convenço de que a prova testemunhal é péssima e o frio do juramento nada vale. A voz é geral acusando o negócio dos africanos e apesar de eu ter procurado todos os homens que me dizem religiosos, probos, etc., sucede que alguns desses [...] dizem, nem ao menos ter ouvido coisa alguma. Veremos Exmo. Sr. se obtém a apreensão dos africanos. ${ }^{13}$

Pouco mais de um mês depois, em 12 de Abril de 1834, Manoel Antonio Silva, juiz de Paz da freguesia de S. Sebastião, despachava mandado de busca às fazendas de José Martins de Azevedo e Manoel Gonçalves Perlonga e ordem de prisão contra os mesmos, em decorrência da denúncia apresentada em 20 de março daquele ano por Antonio José, 30 anos, solteiro, qualificado na condição de "preto livre". Diante do juiz de paz, afirmara:

(...) que na fazenda do Bananal, ou Saco das Bananas, pegada à fazenda de José Martins de Azevedo, um pouco mais para fora, viu trinta escravos, e que ali no Bananal mesmo estavam dois ranchos retirados das pedras onde se recolhiam os africanos, por que não tinham casa; denunciou mais que em Ubatuba se fala muito que José Martins de Azevedo na Fazenda de Tabatinga tinha africanos bem assim que na Lagoinha também havia (...). ${ }^{14}$

Os africanos não foram encontrados, mas o auto de busca lavrado em 20 de abril deu conta do que se passava naquele espaço. Cercada a Tabatinga, apareceu somente José Antonio de Araújo, feitor do dito “capitão José Martins”, que segundo informou teria ido a vila de Ubatuba e desta à Corte. Não obstando ao mandado, o feitor abriu a porta da casa. Lá, foram devassados armários e gavetas, achando-se em uma "canastra grande" seis cartas abertas e uma fechada, apreendidas por apontarem indícios do ilícito trato. As missivas copiadas seguiam destinadas a José Maria Fragoso, datada no Rio de Janeiro aos 31 de março de 1834; a Antônio José Ribeiro, escrita no dia seguinte, também na Corte, por Antonio José Francisco Guimarães; a terceira ao dito Ribeiro, assinada por Jacinto Marçal Lorete em Sepetiba em 3 de abril; a quarta e quinta a Mariano Antonio Belo e Antonio J. Guimarães por A.J.R., ambas assinadas em Tabatinga no dia 12 daquele mês corrente. No mesmo dia seguia outra missiva a José Bernardino de Sá, vinda de Tabatinga, rubricada pelas mesmas iniciais, A.J.R. A última, fechada, seguia a José Antonio Pereira, sem data e remetente registrados.

A apreensão de cartas suspeitas, oriundas da Corte, do litoral sul fluminense e da própria praia de Tabatinga, revelam uma teia de relações complexas que no litoral brasileiro do Atlântico não se reduzia às praias de Ubatuba, envolvendo agentes da Corte e do litoral fluminense. Infelizmente a nós só chegou a missiva dirigida a Bernardino de Sá. Seu conteúdo é revelador de parte da dinâmica do tráfico na clandestinidade: 


\section{Sr. José Bernardino de Sá}

Tabatinga, 12 de abril de 1834

Ontem para uma hora da tarde cheguei a esta com onze dias da saída dessa com a roupa que saí; por que o José Maria não saiu da cidade senão no domingo e eu estive a esperar na Sepetiba até que me desenganei e parti, até agora ainda não sei a gente por que se acha em diferentes portos [pontos] por motivos, assim mesmo já se tem vendido alguma não sendo a da primeira sorte e com alguma avaria e mais se teria vendido se quisessem algum prazo para o ano. Se espera-se tranquilizar algumas coisas, sucedendo assim e juntando-se, aparecendo algum, quem queria vermos o que se pode fazer.

Incluso remeto duas letras uma de seiscentos mil e outra de um conto oitocentos e setenta e dois mil, assinada por João da Costa Gomes Leitão a pagar nessa Antonio Tertuliano dos Santos e a primeira sacada por José Machado a pagar nessa o [dito] ausente a sua ordem. Sirva-se vossa mercê de lhe fazer por ajuste e cobrá-la para suprir as coisas já necessárias, como seja paga logo que seja preciso ao capitão oitocentos mil na forma do primeiro ajuste, e a minha chegada se concluirá o resto ao contramestre João Fernandes, quinhentos mil réis na mesma conformidade, e aos marinheiros a razão de dezesseis mil por mês desde o dia de sua matrícula, e os ditos querendo ficar até que vá pela razão, os deixará ficar, e não querendo os despedirá, mandando para bordo dois negros para serviço do navio e baldeação. Se o contramestre estiver impossibilitado de estar a bordo o dispense, Martins ficará suprindo suas vezes até a minha chegada, fará favor mandar levar cem mil réis a minha casa, desejarei não tenha havido novidade grande no navio, o que não espero já por irem as coisas bem arranjadas e já por serem debaixo de suas vistas. Será um bem se aconteça se demorar bastante tempo. Ansioso estou para saber o que se tem passado, e fico certo que na primeira ocasião não deixará desse particular. Continua a ser como estima. De [vosmecê] [amigo] [ ] [ ] A.J.R. ${ }^{15}$

A missava a José Bernardino de Sá de seu agente em Tabatinga é bastante reveladora. Primeiro demonstra como os responsáveis pela recepção circulavam pelo litoral à espera do negreiro. Nesse caso específico, o imponderável - provocado pelas marés ou pela repressão - parece ter levado o tumbeiro a desembarcar em local imprevisto, fazendo o tal Ribeiro perder a viagem à Sepetiba, mas não os africanos que começavam a ser vendidos em diferentes pontos do litoral. Os primeiros eram àqueles mais debilitados pela escravização em África e pela passagem do meio, vistos como peças avariadas pelo agente de recepção. Muitos, no entanto, ainda eram mantidos sob seu domínio. Ao que parece "os de primeira sorte", mais novos e em melhores condições de saúde, portanto mais caros. A venda e o pagamento, em ambos os casos, eram passíveis de negociação, com amortização à prazo. 
A chegada do navio negreiro era marcada também pelos ajustes a serem feitos com os negociantes envolvidos e toda a tripulação. Nesse sentido, o pagamento envolvia uma série de descontos de letras entre os sujeitos responsáveis pelo abastecimento das provisões do navio e os próprios marinheiros. As duas primeiras letras a serem pagas por Gomes Leitão parecem quitar parte da estruturação da expedição e armação do negreiro. As demais, acertavam os salários do capitão, contramestre e marinheiros. Os dois primeiros receberiam, respectivamente, 800 e 500 mil réis, enquanto os demais míseros 16 mil réis por mês trabalhado, desde o início da expedição até o desembarque, atestando o já conhecido estado de penúria da tripulação (RODRIGUES, 2005; REDIKER, 2011). Contramestre e marinheiros receberiam o pagamento na Tabatinga do próprio Ribeiro. Querendo, continuariam no navio, ou seriam dispensados e substituídos por dois cativos da fazenda experimentados no mar e nos serviços navais, ou no caso do contramestre por um tal Martins, provavelmente, José Martins de Azevedo, tido por dono da Tabatinga, que assumiria suas funções até a chegada de Ribeiro. No mais, esperava que não houvesse "novidade grande no navio", ou seja, que a taxa de mortalidade fosse a calculada e que revoltas, relativamente comuns nos negreiros, não tivesse comprometido a expedição, "bem arranjada” por seus organizadores.

Note-se que em nenhum momento o remetente da missiva se refere à cativos, escravos ou mesmo carga humana. Há claramente um cuidado genuíno na sua escrita em vista da repressão no Atlântico e em algumas partes do litoral brasileiro. A marca da pirataria e da ilegalidade que acompanhava o comércio negreiro naqueles anos ampliava o medo dos seus agentes na troca de correspondências. Não por acaso, as missivas encontradas na busca e apreensão estavam dentro de canastras trancadas, arrombadas na incursão. A linguagem cautelosa e, por vezes, cifrada visava proteger os corruptores das leis que seguiam num comércio ilícito e infame. No entanto, os indícios eram tantos e tão fortes que não impediram a apreensão dos papéis que certamente revelariam mais se tivessem disponíveis em plenitude até o tempo presente.

Embora apenas uma carta tenha chegado até nós, a correspondência trocada entre Pimenta Bueno, Juiz da Comarca, com a Presidência da Província, apresenta indícios sobre as missivas que se perderam. De quebra coloca novamente a Tabatinga e seu porto no centro do tráfico negreiro na zona de Ubatuba à São Sebastião:

(....) que saiba, que os tais negociantes de carne humana denominam fardos, volumes, fazendas os pretos africanos como estou informando e informará a V. Ex. ${ }^{a}$ ao Ten. Coronel ; que saiba que o porto de Tabatinga onde são datadas pela maior parte as ditas cartas e que aparece como uma espécie de alfândega de bastante giro é o sítio de José Martins de Azevedo; que reflita sobre a carta $n^{\circ} 6$ e veja que já então se havia espalhado os africanos que ainda existiam a venda por diversos pontos e sobre a carta $\mathrm{n}^{\circ} 8 \mathrm{em}$ que ainda eles pretendiam [tranquilizar] algumas caixas para que eles aparecessem e conservassem de que quando se fez a diligencia já não era tempo de conseguir resultado algum. 
Verá V. Ex. ${ }^{a}$ por essas cartas quais as pessoas da llha Grande e Rio de Janeiro que se acham indiciadas de sociedade em semelhante comércio. Além dessas cartas apreendeu-se mais uma que ainda se acha fechada em poder do juiz de paz de São Sebastião e que pela letra mostra ser de Jacinto Marcal Loreti por quem é escrita a carta $n^{\circ} 5$, convinha bem abri-la e vê-la por que tendo durante muita estada ali havia novo desembarque, ela deveria tratar dele indiciado por essas cartas, já V. Ex. ${ }^{a}$ via pelo sumário que Ihe transmiti que João Alves da Silva Porto que durante minha estada em São Sebastião passou por ali sem que eu o visse e também tido como interessado no negócio e a fazenda da Lagoinha pertencente a sua sogra como um dos pontos de desembarque.

Agora chega a minha vista a ordem do Exmo. Ministro da Justiça mandando expulsar do império por semelhante crime o português Anastacio José Ribeiro, que é justamente o correspondente das cartas $n^{\circ} 1^{\circ}$ e outras assinadas pelas iniciais A. J. R., talvez agora conviesse mais tratar-se de punilo e apreender seus bens para a multa da Lei e garantia da reexportação dos pretos, quando seguros (...) (Grifos meus). ${ }^{16}$

Na pena de Pimenta Bueno, a fazenda-sítio Tabatinga aparece como "uma espécie de alfândega de bastante giro" onde aportam os negreiros com suas "cargas" humanas. Parece que dali os africanos seguiam para sítios conexos. Podiam descer em outras fazendas também, como no caso da Lagoinha, de propriedade da sogra de João Alves da Silva Porto. Mas considerando de onde partiam as cartas dos negreiros, parece inconteste que a fazenda mantida por José Martins de Azevedo era o centro litorâneo de uma empresa maior, com ramificações no sul fluminense, na Corte e certamente na costa da África. A sociedade, como vimos, engendrava fazendeiros no litoral paulista e fluminense, autoridades locais e negociantes da praça do Rio de Janeiro com agência atlântica, como no caso exemplar de José Bernardino de Sá. Na única carta que tivemos acesso, o link Rio de Janeiro-Tabatinga se dera entre o dito Sá e o misterioso A.J.R, que agora sabemos se tratar de Anastácio José Ribeiro, a quem o Ministério da Justiça decretara a extradição do Império do Brasil por envolvimento com o tráfico. Protegido nas redes da Corte, Sá passara incólume.

Nos documentos pesquisados por Guisard Filho - autor que abre nosso texto - despontam exatamente os mesmos espaços denunciados por Pimenta Bueno, entre 1833 e 1834, como os lugares armados para finalização dos empreendimentos traficantes na clandestinidade. Portos, fazendas e negreiros se estruturavam e se fixavam na região de Ubatuba e São Sebastião, como denotam as denúncias do final da década de 1830:

Aos treze dias do mês de março de 1838, nesta Secretaria de Polícia compareceu Euzebio José Rodrigues Freitas, negociante, morador na rua Formosa da Cidade Nova, n. 22, e em virtude do despacho desta data em sua petição foi-lhe tomada a denúncia seguinte: que na Fazenda denominada Tabatinga, próxima a ilha de São Sebastião, de que é proprietário José Bernardino 
de Sá, morador nesta Corte esta presente sendo um dos mais frequentados pontos de desembarques de africanos boçais, e que ultimamente ali aportaram, em janeiro, dois barcos carregados deles, pelo que indignadas algumas pessoas das vizinhanças, reuniram-se com armas para dispersa-los, e fazer, com isto, que tais contrabandistas deixassem aquele porto, cuja frequência já tornava-se escandalosa; diga mais, que o dito José Bernardino para melhor fortificar-se ali havia construído uma espécie de forte de madeira, guarnecido de doze ou treze colonos, e muitas outras pessoas de artilharia para defender o desembarque de seu contrabando, outro sim declarou que estava a chegar ali o Brigue Escuna Paquete de Loanda - outrora - Espadartes que é pertencente ao mesmo Sá, com nome suposto cujo brigue é guarnecido por duas peças ... que é desmontado e oculto no porão logo que aqui entrar. $E$ dando por concluída a denúncia assinou o presente termo por achá-lo conforme - Euzebio José Roiz [Rodriguez] de Freitas. Está conforme - Joaquim José Mora. Maia (apud GUISAR FILHO, 1940, p. 192).

A denúncia é riquíssima e reveladora dos meandros do crescimento do comércio negreiro naquela costa. A fazenda da Tabatinga, a mesma que em junho de 1833 pertencia ao capitão José Martins de Azevedo e estava na mira da chefatura de polícia de São Paulo sob suspeita de acoitar cerca de 600 africanos recém desembarcados, nos idos de março de 1838 era propriedade de José Bernardino de Sá. Futuro comendador nos anos de 1840, Barão e Visconde de Vila Nova do Minho na primeira metade da década de 1850, Bernardino de Sá se tornou o maior traficante de escravizados do Atlântico sul no segundo quartel do oitocentos (CAPELA, 2012).

No entanto, àquela altura, embora ainda estivesse um pouco distante do que iria se tornar, ao que parece, havia adquirido a fazenda da Tabatinga com o intuito de convertê-la em porto seguro aos seus negreiros. Ou ainda, considerando a troca de missivas apreendidas naquela propriedade em 1834, é possível que Tabatinga já pertencesse a Bernardino de Sá, que a mantinha em sociedade com o capitão José Martins. Note-se que Sá não residia em Ubatuba, era negociante em ascensão na Corte imperial. Seu interesse numa fazenda naquele litoral era meramente transformála em porto de recepção aos seus tumbeiros e redistribuição dos cativos recém chegados. Nisso, antes do fim da década de 1830, lograra sucesso: a sua praia havia se convertido "em um dos mais frequentados pontos de desembarque de africanos boçais", e a frequência dos contrabandistas naquele porto "escandalosa".

Joaquim de Paula Guedes Alcoforado, traficante redimido à serviço do abolicionismo inglês e brasileiro, e estrategista do Ministério da Justiça do Brasil no desmonte do tráfico, entregara aos dois impérios detalhado relatório sobre as atividades traficantes no litoral do Vale do café entre 1833 e 1851. Nele destacara que "José Bernardino de Sá e um tal Veiga estabeleceram desembarque próximo a São Sebastião, lugar denominado Itabatinga" (FERREIRA, 1995; PESSOA, 2018b). Apesar do equívoco, não há dúvidas que Alcoforado se referia à Tabatinga, área vinculada ao tráfico, no mínimo, desde 1833, e que entre o final de 1834 e o início de 1838, foi adquirida pelo 
negociante português com o claro intuito de transformá-la em espaço especializado na recepção, recuperação e redistribuição de africanos na clandestinidade.

Tudo indica que a escolha foi muito bem planejada. Tabatinga estava justamente nos limites do município de Ubatuba e São Sebastião, afastada, portanto, dos centros das respectivas vilas. ${ }^{17}$ Protegida pelo vazio jurisdicional, a praia, convertida em porto negreiro, era cortada pela foz de rio homônimo, que servia à fazenda de José Martins e Bernardino de Sá como suporte ao seu funcionamento, desde a atracagem, desembarque e redistribuição dos africanos. Até mesmo o próprio desenvolvimento produtivo da pequena lavoura existente, possivelmente, estava vinculado às demandas de recuperação dos africanos recém-chegados.

A denúncia deixa transparecer também uma estrutura, ainda rudimentar, montada para o apoio logístico ao tráfico de africanos na clandestinidade. Bernardino de Sá havia mandado construir uma pequena fortificação de madeira, com guarnição permanente de cerca de uma dúzia de colonos livres armados, além de "muitos" outros homens de artilharia que no momento do desembarque prestariam o suporte e a segurança necessários à finalização do empreendimento negreiro. A violência do trato e do navio negreiro, experimentada por todos aqueles que suportavam ou padeciam na "passagem do meio" (REDIKER, 2011), reatualizava-se nos agentes que para além de impedir o roubo de escravos por outros piratas, prática comum nas praias do tráfico (CARVALHO, 2012), garantiam por meio da tortura a ordem escravista e o cativeiro ilegal de homens, mulheres e muitos jovens e crianças que experimentariam as agruras que despontavam na terra de branco.

Em 21 de abril daquele ano, pouco mais de um mês após a denúncia na Corte, a presidência da província de São Paulo despachara portaria às autoridades locais. Anexando a denúncia, cobrava maiores informações sobre a fazenda-negreira e a pequena fortaleza de Sá em São Sebastião. De maneira emblemática, somente em 10 de junho, quase 3 meses após a denúncia na Secretaria de Polícia da Corte, o juizado municipal - na rubrica de Manoel Gonçalves dos Santos - ordenava ao juiz de paz "dar busca no indicado lugar (...) apreendendo africanos que ali existirem e procedendo na forma da lei contra seus transgressores" (apud GUISARD FILHO, 1940, p. 191). No dia 20 daquele mês, José Bernardino "ou a quem suas vezes fizer diretor, administrador, ou morador na dita fazenda" era notificado para que a franqueasse, a fim de ser cumprida a diligência, o que só se deu no final do mês, como vemos:

(....) aos 29 dias de junho do dito ano [1838] no lugar denominado Fazenda de Tabatinga, próximo à llha de São Sebastião (...) aí informando-me achar-se Paulo José como feitor, intimeiIhe o mandado de busca, que Ihe li e declarei, e o dito feitor imediatamente franqueou a Casa da fazenda mencionada (...) entramos e efetuou-se a busca procedendo-se os necessários exames minuciosamente em todos os quartos, alcovas e mais lugares conforme se exige em objeto de tanta importância e não se encontrou africano algum boçal importado por contrabando, nem peças de artilharia. Achando-se a sobredita fazenda cercada na circunferência com muro de pedra e barro ainda não acabado, 
e circunscrevendo uma vasta pastagem na qual estão muito animais vacum e cavalar; achando-se, outrossim, oito escravos ladinos, sendo três crioulos, um pardo e quatro de nação, todos [ ] [ ] da casa, bem como acham-se seis ilhéus, casados, com família, naturais de Portugal, tratando das lavouras a exceção de alguns destes que existiam gravemente enfermos, não se achou nenhuma mais pessoas, se não que o sobredito feitor Paulo José com sua mulher, os referidos ilhéus e os oitos escravos que foram declarados (...)

Não espanta que não encontrassem nenhum africano recém chegado, àquela altura - 3 meses e meio da denúncia -, já amargavam seu cativeiro serra acima. Os negreiros já estavam em seu retorno à África, provavelmente, em alguma parte da imensidão do Atlântico, ou mesmo atracados na costa centro-ocidental daquele continente. Mesmo considerando o tempo gasto na troca dos ofícios, chama bastante atenção a morosidade na execução da diligência, assim como a notificação aos administradores da fazenda, dias antes da incursão das autoridades locais. Meramente protocolar, a diligência já sabia exatamente o que iria encontrar. No entanto, chama atenção as entrelinhas da incursão.

Nos idos de 1838, Tabatinga era uma pequena fazenda, com 8 cativos, metade dos quais africanos. Além deles, os colonos portugueses, citados na denúncia feita por Eusébio José Rodrigues de Freitas em março de 1838, lá estavam. Segundo o feitor Paulo José, ao que tudo indica, também administrador da propriedade, todos labutavam as lavouras existentes e a "vasta pastagem" de gado vacum e cavalar. Não sabemos exatamente o que cultivavam, tampouco o destino do gado, mas não é improvável que a própria produção da fazenda atendesse ao sustento dos recémchegados e sua recuperação nutricional, antes de seguirem aos seus cativeiros. Era comum que propriedades destinadas à finalização dos empreendimentos negreiros cumprissem esse papel (CARVALHO, 2012). Assim como poderiam funcionar como "territórios de espera" (VIDAL, 2016), onde milhares de pessoas na imensidão das Américas chegaram e permaneceram por curtos períodos, experimentando o contato com um novo mundo que se abria a partir daqueles espaços.

No final de 1840, a fazenda da Tabatinga voltava novamente ao centro da atenção das autoridades locais. Em 06 de dezembro de 1840, João Alves da Graça, juiz de paz suspenso da vila de Ubatuba, denunciava a existência de 700 africanos nas fazendas da Lagoa e da Tabatinga, propriedades atribuídas à Francisco Xavier Duarte Veiga e José Bernardino de Sá. Os africanos haviam desembarcados de dois brigues que àquela altura se achavam fundeados na Praia do Bonito. O denunciante, deposto do cargo por suspeita de envolvimento com o tráfico ilegal, arrematava sua denúncia acusando Antônio Egídio da Cunha, juiz de paz suplente em Ubatuba, de negligência com os desembarques e os barracões do tráfico. Vale lembrar que Bernardino de Sá e Veiga figuravam como parceiros no famoso relatório de Joaquim de Paula Guedes Alcoforado (FERREIRA, 1995; PESSOA, 2018b). Hoje sabemos que o "tal Veiga" era Francisco Xavier Duarte Veiga, a época dono da fazenda da Lagoa, e sócio de Sá nas traficâncias no litoral paulista. Em meados dos anos de 1850, assim como a 
Tabatinga, a Lagoa será arrolada no espólio de José Bernardino de Sá como parte de seus bens em Ubatuba.

A incursão, no entanto, foi realizada em 19 de dezembro de 1840. Antonio Egídio, o inspetor de quarteirão e o escrivão foram acompanhados da pouca força de que dispunham, três guardas, e mais testemunhas em "rigoroso exame e busca nas fazendas de Francisco Xavier Duarte Veiga e José Bernardino de Sá, naquelas praias da Lagoa e Tabatinga”. A retórica do ofício era de guerra, autorizando os oficiais "empregarem o grau de força necessária para efetuá-la". No mesmo 19 de dezembro as duas propriedades foram devassadas, o que denota a proximidade das unidades ou mesmo que o rigor das autoridades não era tão grande assim. Não por acaso, nada foi encontrado. Nem africanos, nem vestígios da tripulação e das embarcações, tampouco cartas ou correspondências, como aquelas que apareceram em 1834. Enfim, nada que incriminasse as fazendas de Veiga e Sá e suas agências. ${ }^{18}$

No final de dezembro de 1840, sob pressão, o juiz Egídio da Cunha inicia a convocação das testemunhas para formação de "processo informatório". Às 10h do dia 22, as quatro testemunhas convocadas iniciaram seus depoimentos. De maneira unânime afirmaram nada saber, enfatizando, ainda, como disse Sebastião que "não Ihe costa que semelhante comércio se pratique naquelas fazendas e mesmo neste distrito". A negativa se repetia a cada depoimento, da mesma forma que os quatros reconheciam, por "ouvir dizer", a existência de "dois barcos", encontrados por uma escuna de guerra, "sem tripulação alguma e inteiramente abandonados", como afirmara Isidro, na Ilha de Tamanduá, na fronteira entre Ubatuba e São Sebastião e, literalmente, em frente à praia da Tabatinga. ${ }^{19}$

A conclusão do "processo informatório" e sua publicação é paradigmática do que estaria por vir:

\begin{abstract}
Publicação
Aos 23 dias do mês de dezembro de 1840 nesta vila de Ubatuba em meu cartório por parte do juiz de paz suplente o capitão Antonio Egidio da Cunha me foi entregue estes autos com a sua sentença retro na qual manda impor silêncio e a houve por publicada em minha mão de que para constar lavro esta, eu Adriano Antonio da Rocha, escrivão interino que o escrevi". ${ }^{20}$ (Grifos meus)
\end{abstract}

A imposição do silêncio, no início da década de 1840, era modular. Apesar de ser transformada em política de Estado na década seguinte, como bem demonstraram Beatriz Mamigonian (2011; 2017) e Sidney Chalhoub (2012), impressiona que esse processo tenha se iniciado tão precocemente. Isso não significa que a determinação fosse acatada por todos. O denunciante João Alves da Graça não pretendia passar por mentiroso, e logo após a conclusão do processo citado, remetia missiva à Câmara Municipal de Ubatuba acusando "a todas as autoridades judiciais desta vila como omissas ou convenientes no ilícito comércio de africanos". As respostas dos juízes de direito interino, do município, de paz e do promotor público vieram em seguida e 
foram remetidas à Presidência da Província. Todos acusavam a denúncia de Graça de falsidade e calúnias "somente para cevar o ódio". Egídio da Cunha, por exemplo, atribuía a denúncia "ao gênio do mal, [que] é quem guia a falsa pena do denunciante Graça e seu mentor Lacerda para tudo baralhar caluniosamente”. Com as autoridades judiciais, concordavam os representantes da Câmara, para quem o denunciante "tem lançado mão dessas falsas denúncias à V. Exa. somente por ódio, vingança e com o fim de descreditar os seus adversários políticos, nunca, jamais, por zeloso cumprimento da lei, muito menos por bem da moralidade". ${ }^{21}$

O silêncio rompido por Egídio da Cunha certamente tinha relação direta com as disputas locais, e com seu próprio afastamento do juizado de paz. Nesse sentido, realmente não havia compromisso com a lei de 7 de novembro de 1831, tampouco com a moralidade pública. O que não quer dizer que não falasse a verdade e que os desembarques não tivessem ocorridos. Os africanos não estavam mais na Lagoa e na Tabatinga, mas os navios estavam lá, em frente àquelas propriedades, seguiam abandonados na llha de Tamanduá. As disputas políticas locais suspenderam temporariamente o silêncio que vigoraria durante toda a década de 1840 , salvo raríssimas exceções.

Não à toa, como é de praxe na documentação produzida pelas autoridades brasileiras a partir década de 1840, denúncias, incursões e referências ao comércio clandestino de africanos desaparecem dos escaninhos das autoridades policiais e judiciais do Império, nos níveis locais e provinciais. A assunção conservadora, chamada a época de "Regresso", sistematizou o tráfico como política de Estado (BETHELL, 2002; MAMIGONIAN, 2011; PARRON, 2011). A partir daí contava com o compromisso do Império de não produzir prova que materializasse o crime consentido com amplo apoio social. A perspectiva era não produzir prova contra si, que atestasse a flagrante e silenciada ilegalidade da escravidão no Império do Brasil. Somente após a segundailegalidade, efetivada no início de 1850, as fazendas-negreiras voltam a aparecer nos registros brasileiros, depois de passarem mais de uma década eclipsadas pelos arranjos políticos em favor do contrabando negreiro.

\section{A $2^{\mathrm{a}}$ ilegalidade e a superação do silêncio}

Em fevereiro de 1851 toda a costa da ilha de São Sebastião seria novamente devassada. Em cumprimento ao aviso expedido pelo Ministério da Justiça de 16 de janeiro de 1851, a Presidência da Província de São Paulo mandara fixar destacamento na baía do Sombrio, enseada encravada na parte de fora da llha Bela, voltada para a imensidão do Atlântico. O então chefe de polícia - nosso já conhecido Joaquim Firmino Pereira Jorge -, atendendo às ordens do Ministro Eusébio de Queiroz para devassar os conhecidos portos negreiros da região, desembarcara no dia 01 de fevereiro de 1851 no Sombrio. ${ }^{22}$

O escaldado Pereira Jorge encontrara "as fazendas Sombrio, Calhetas e Figueira, que existem todas dentro de uma só baía”. Com os mandados de busca e apreensão expedidos, alertava que a diligência seria feita de modo "que nada se podia ocultar", 
uma vez que por ali não era esperado. Iniciando seus trabalhos pela fazenda do Sombrio, talvez se regozijasse com o sucesso na empreitada:

\begin{abstract}
Auto de busca e Apreensão - Ao $1^{\circ}$ de fevereiro de 1851 na Fazenda denominada - Sombrio - em cumprimento ao ordenado pelo governo da província foi vindo o Dr. Chefe de Polícia (...) [e] passou a examinar as casas da referida Fazenda que são um grande rancho coberto de telha sobre o morro, e dez casas cobertas de palha, [era] acima das quais, na proximidade do mar, já deteriorada, foi encontrada grande porção de grilhões - vulgarmente machos de ferro, e igual porção de toneis, pipas, [quartelas] próprias peças de [aqueada]. E por isso tais objetos sejam visivelmente destinado para o tráfico de africanos, ordenei (...) que fosse todos inventariados, sendo os de ferro depositados em mão de pessoa segura, e o vasilhame, depois de avaliado, inutilizado na conformidade das ordens que recebera, visto não ser possível pela sua grande quantidade removê-lo para outro lugar, por falta de meios de transporte.
\end{abstract}

A contundência do que encontrara não deixava quaisquer dúvidas ser àquela fazenda parte de uma grande estrutura voltada ao tráfico de africanos. Lá estava o barracão, "um grande rancho" "de madeira” "bastante arruinado". Como detalha adiante, dentro dele foram encontrados "os cem pares de grilhões, conhecidos por machos de ferro, bem como dezesseis argolas pertencentes a outros machos". As casas menores serviam de morada aos feitores e administradores do espaço que em África se chamava, acertadamente, de presídio. Cumpriam também o papel de apoio logístico ao empreendimento traficante, armazenando pipas, barris, mantimentos, equipamentos dos negreiros e a própria equipagem do navio por alguns dias.

Animando com que vira, Pereira Jorge seguira para o "sítio" Calhetas. Lá registrara 48 pipas e 28 "quartelas" que concluíra terem servido "para arqueada de navios". Sem muito mais a avaliar, passara ao "sítio" Figueira, distante do primeiro "uma légua e meia mais ou menos". Ali residia o proprietário do pequeno complexo negreiro, ou ao menos seu principal administrador. No que parecia ser a sua sede, escondia-se ...

(...) um trabuco, uma pistola, quatro clavinas de adarme doze, vinte e sete delas de adarme dezessete, duas espingardas lazarinas, uma coronha e fecho de um trabuco, nove baionetas, seis [rifes], quatorze espadas [curtas], três ditas mouriscas, sete lanças com os competentes cabos, duas caldeiras de ferro, tendo cada uma quatro palmos de altura, e quatro palmos e duas polegadas de largura... ${ }^{23}$

Parece evidente o nível de violência que envolvia o comércio negreiro (REDIKER, 2011). À rigor era esse arsenal de guerra que limitava a chance de revolta dos africanos no ato do desembarque e em suas curtas estadas naqueles "territórios de espera" (VIDAL, 2016). Chama atenção também as caldeiras - "para fazer-se a comida de grande número de pessoas", as "grandes colheres de folhas de flandres" e "outras tantas escumadeiras com cabos de ferro" usados por hábeis cozinheiros responsáveis 
por alimentar duzentas, trezentas e, não raro, mais de quinhentas pessoas famintas e muito debilitadas.

Segundo fora informado, "por pessoa que tinha razão de saber tudo quanto durante esse tempo ali se passou", os grilhões, as caldeiras e outros objetos desembarcaram de navios pertencentes à Manoel Pinto da Fonseca, muito embora aquelas três "fazendas" não Ihe pertencessem. Em fevereiro de 1850 eram propriedades de Antônio Lourenço de Freitas, que as havia adquirido em 22 de fevereiro de 1849. Freitas dizia tê-las comprado para transferir o estabelecimento de pesca das baleias que possuía em outra propriedade não muito adequada àquela atividade. Se pretendia dar continuidade ao tráfico, por longos anos ali exercido, deveria "abandonar tal intento" diante da repressão que se anunciava.

No entanto, Pereira Jorge parecia estar convencido que aqueles objetos, assim como toda estrutura, parte já arruinada, era herança dos antigos proprietários: Antonio Fernandes Coelho, residente no Rio de Janeiro, e seu sócio, Francisco Antonio Cortez, morador de Vila Bela da Princesa. Contra Coelho e Cortez pesava o passado, "pois foi enquanto possuíram aquelas fazendas que nelas se fez desembarque de africanos". Para Pereira Jorge eram eles que deveriam responder perante a justiça e não o novo proprietário que comprara a fazenda há poucos meses, com todos aqueles objetos que ali já existiam. O problema era: deveria o chefe de polícia questionar o histórico de envolvimento daquelas propriedades com o tráfico? Deixava ao Presidente de Província a difícil tarefa de "resolver o que lhe parecer mais justo e conveniente, visto que fiquei em dúvida se deveria ir envolver-me com o passado". ${ }^{24}$

De lá, o chefe de polícia seguira para a cidade de Santos, onde no dia 09 de fevereiro devassou a fazenda Perequê de propriedade do famoso português Valencio Augusto Teixeira Leonil, que àquela altura já havia sido absolvido pelo tribunal júri de Santos pelo crime de contrabando de africanos. Acompanhado do feitor João José Vasconcelos Pinto percorreu "os edifícios" da propriedade. Em um deles, contíguo a casa de morada, em um quarto fechado, deparou-se com uma "uma caldeira de cobre" à semelhança das anteriores "para o preparo de grande quantidade de comida". Adiante, estavam outras provas mais contundentes de que reincidia no mesmo crime:

(...) quatro armazéns todos constituídos de tarimba, sendo dois maiores que os outros; e oferecendo cada uma daquelas acomodações para quatrocentas pessoas mais ou menos, de vista do que ordenou o chefe de polícia que fossem avaliadas as ditas tarimbas e depois inutilizadas. Percorrendo ainda as [senzalas] dos escravos e demais edifícios nenhum sinal mais encontrou-se relativamente do tráfico. Achou-se colocado na praia um mastro com mastaréo e degraus até os [ ] que pareceu destinado para vigiar-se embarcações, e fazer-lhes sinais, e que foi igualmente mandado avaliar e inutilizar ...25

Impressiona a dimensão das ditas acomodações que poderiam ocultar os sobreviventes de três a quatro negreiros que ali chegassem num curto espaço de tempo. As tarimbas "já usadas" denunciavam a movimentação recente daquele presídio. 
Os tumbeiros que se aproximassem contariam com sinalização fornecidas do "mastro com mastaréu e degraus que esta[va] colocado na praia”. O mastro servia como "atalaia" de orientação aos capitães que se aproximassem, fossem eles os negreiros que seriam acolhidos, ou os ingleses a serem repelidos, ou mesmo assassinados, como no famoso caso do cruzador Refliman, no qual Leonil fora indiciado como acusado principal.

O arsenal apreendido, assim como as caldeiras e demais utensílios, deveriam ser remetidos à Corte. O problema era achar quem os quisesse transportar. Segundo informara a Presidência da Província ao Ministério da Justiça: "os donos das embarcações mercantes recusam-se em transportar os objetos com medo de serem apreendidos pelos ingleses". ${ }^{26} \mathrm{O}$ excesso de precaução ilustra a dimensão da repressão naquele contexto.

A devassa feita naquelas propriedades desarticulou os desembarques na costa de São Sebastião, mas não parece tê-los interditado. Segundo informara as autoridades inglesas do vapor de guerra Plember ao juiz do termo de São Sebastião e Vila Bela da Princesa, planejava-se um desembarque de africanos na contra costa da ilha, "lugar denominado Sombrio ou Toca" Tratava-se do Brigue/Escuna Tentadora, procedente de Havana. O Vapor Paraibuna, atuante na carreira de São Sebastião ao Rio de Janeiro, coadjuvaria no desembarque, além de um proprietário da ilha que "mandara fazer grande porção de roupa de algodão própria para semelhante gente". As suspeitas aos olhos das autoridades não se confirmaram, possivelmente porque o negreiro decidiu mudar a rota de sua atracagem. ${ }^{27}$

As fazendas negreiras de José Bernardino de Sá, situadas nos limites entre Ubatuba e São Sebastião, continuavam bastante ativas no início dos anos de 1850. Prova disso era a discussão sobre a construção de um "distrito de subdelegacia compreendendo as fazendas Lagoa, Tabatinga, S. Pedro e Lagoinha”. Procurava-se para o cargo "pessoa idônea que como subdelegado fosse ali residir e reprimir suficientemente o tráfico". No entanto, a Presidência da Província informava ao Ministério da Justiça que "não me [era] possível cumprir dita autorização, porque as pessoas em quem eu confiava para essa comissão importante, sendo consultadas não a quiseram aceitar". ${ }^{28}$

O desafio era grande, sobretudo porque se tratava de área de domínio do todo poderoso José Bernardino de Sá, naquele momento já Barão de Vila Nova do Minho. Segundo informara o delegado de polícia de São Sebastião - José Antonio da Silva - o esforço era em vão: "não acho possível criar-se ali Subdelegacia porque o pouco povo que tem é ignorante, e todos estão acostumados a render respeito aos administradores das Fazendas". ${ }^{29} \mathrm{O}$ imbróglio se dera porque as fazendas ficavam astutamente fincadas num vazio jurisdicional, sob a jurisdição de Ubatuba, mas longe demais de suas forças policiais. Segundo seu delegado, no lugar "(...) não tem quase povo por se achar quase todo o território abrangido pelas 4 grandes fazendas chamadas da Tabatinga, Lagoa, S. Pedro de Alcântara e Lagoinha, na grande extensão ocupadas por essas fazendas não existem senão meia dúzia de fogos". ${ }^{30}$ Estavam mais próximas à subdelegacia de Caraguatatuba, pertencente ao município de S. Sebastião, que, no entanto, não detinha sob elas jurisdição. A solução efetiva era 
estender os limites de São Sebastião até o rio Maranduba para englobar àquelas propriedades. A medida, por depender de aprovação da Assembleia Provincial de São Paulo, parecia a mais longa. Enquanto isso não ocorria mantinha-se estacionado um destacamento na porteira da fazenda de Tabatinga para coibir casos como o do Brigue Escuna Fidelidade esperado naquelas praias naquele momento. ${ }^{31}$

A despeito de toda estrutura de repressão, mesmo após o famoso caso do negreiro Mary Smith, que em São Matheus (ES) desembarcara os últimos africanos que se tem notícia no Império, continuavam a circular suspeitas de associações para o tráfico. Em Campinas, por exemplo, em abril de 1856, circulava a informação de que alguns fazendeiros ricos daquele município haviam constituído uma sociedade com a finalidade de organizar novas importações de africanos. ${ }^{32}$

Um pouco antes, nos últimos dias de 1854, em documento reservado, a presidência da província levava ao conhecimento do Ministério da Justiça matéria semelhante:

\begin{abstract}
Reservado
Illmo Exmo Sr.

Acuso a recepção da portaria reservada de $V$ Exa. datada de 11 do corrente, no qual, comunicando-me haver bem fundada suspeita de existirem uma liga entre pessoas importantes de Jacareí e Paraibuna para o tráfico de africanos (...). Em princípio de novembro precedente chegou a esta Vila no Vapor - Carioca - um indivíduo chamado Bernardino Martins de Ferreira Faria, português, residente em Niterói, e que se diz ter obtido outrora alguma fortuna envolvendo-se no tráfico direto de Africanos. Chegado a esta Vila, dirigiu-se a fazenda da Lagoinha (que antigamente foi ponto de desembarque) em companhia de Luiz Alves da Silva Porto, atual proprietário desta fazenda, e dali ambos seguiram para a Vila de Paraibuna, em cujas imediações o dito Porto tem uma situação e alguns escravos, que o dito Faria ia comprar, segundo constava, sendo esse o fim da viagem (...) Mas, conquanto eu não tenha o menor motivo para desconfiar dessa viagem, é possível que a compra de escravos fosse um pretexto [ ] para acobertar fins sinistros, ou para desviar a atenção para um ponto diferente, e, em todo o caso, como os precedentes do indivíduo justificam até certo ponto alguma desconfiança, eu entendi de meu dever comunicar a V. Exa. esta ocorrência ... ${ }^{33}$
\end{abstract}

As suspeitas sobre Bernardino Martins de Ferreira Faria e a fazenda da Lagoinha não eram infundadas, contra eles pesavam o histórico de envolvimento no ilícito trato. Não à toa, no ano seguinte, estampariam as páginas dos jornais. Na edição de quinta-feira, 9 de Janeiro de 1856, o Jornal do Commercio alertava o governo imperial sobre o caso que chegara à redação de fonte "sisuda" e "idônea". Tratavase do comandante do vapor de Guerra D. Pedro que revelara o caso ao jornal antes mesmo de reportá-lo aos seus superiores, fato que o juiz de Ubatuba considerava "uma imprudência". Aos leitores, ficava a impressão de que "não podemos concluir que acabaram para sempre as tentativas isoladas de um ou outro africanista audaz": 
Dizem-nos que nos primeiros meses do ano passado estivera em Ubatuba um indivíduo que procurara aliciar vários fazendeiros do lugar de serra acima, para entrarem com ele em uma especulação do tráfico.

Declarou lhe esse indivíduo que em New York estava organizada uma grande associação com ramificações no Brazil, Antilhas, e Costa da África, que essa associação mandara criar escolas da língua portuguesa em alguns pontos da África onde ainda se faz o tráfico; que os negros logo depois de comprados frequentariam essas escolas, e que apenas soubessem 0 idioma do nosso país, como o sabem os nosso ladinos, seriam embarcados para o Brazil e aqui aportariam vestidos de algodão de Minas à imitação dos nossos escravos.

Acrescentava o provocador que, a despeito de toda a vigilância do governo imperial, a serra compreendida entre S. Sebastião e Ubatuba estava preparada e picada em uma das extremidades para dar fácil e oculto transito aos negros; que quanto ao desembarque ficaria isso por conta de oficiais experientes e peritos que de dez vezes, nove sabem iludir a vigilância dos cruzadores; que se por acaso depois de efetuado o desembarque, e antes de internados os negros, saltasse alguma força em terra para apreende-los, seriam escondidos num vasto subterrâneo que existe na fazenda da Lagoinha, e do qual só tinha conhecimento o homem a quem o finado proprietário dessa fazenda revelara o segredo; e finalmente, que no caso de serem varejadas as fazendas de serra acima que tivessem recebido africanos, ninguém os distinguiria dos antigos.

(...)

Repetimos que temos estas informações de pessoa fidedigna. O governo, mandando examinar se a serra indicada está picada; se na fazenda da Lagoinha existe o subterrâneo de que se trata o nosso informante designa o lugar do esconderijo, e ordenado que sejam inquiridos alguns dos convidados em Ubatuba, poderá adquirir luminosos conhecimento que o aproximem de verdade. O nosso dever está comprido. ${ }^{34}$ (Grifos meus).

Teria efetivamente existido um calabouço naquela praia para ocultar os africanos recém chegados? O redator da matéria do Jornal do Commercio considerava inverossímil, mas não impossível. Outros trechos do relato que parecem surreais já foram confirmados pela historiografia, como no caso da associação formada em Nova Iorque com traficantes que haviam atuado no Brasil, e agora dedicavam-se ao ilícito trato entre Cuba e a Costa da África. A Companhia Portuguesa, como à época foi chamada, reunia gente como Ruviroza y Urgelles, Antônio Severino Avellar, Francisco Flores e outros indivíduos que conformavam a fina flor do tráfico ilegal de africanos para o Brasil entre as décadas de 1840 e 1850 (FERREIRA, 2012).

As autoridades imperais souberam do caso pelos jornais, e ao que parece, deram crédito aos relatos encaminhados a investigação à autoridade competente. Antônio Barbosa da Cunha, juiz municipal de Ubatuba, repassara ao Ministério da Justiça o que descobrira por meio um fazendeiro da região que afirmava ter sido convidado 
pelo dono da Lagoinha a embarcar na aventura traficante. Em 7 fevereiro de 1856, o conselheiro Nabuco era colocado a par daquele imbróglio:

(...) Inteirado da importância que V. Ex. ${ }^{a}$. liga a descoberta do subterrâneo da fazenda da Lagoinha cumpre-me declarar que (...) o fazendeiro que me fez as revelações que então transmiti estava ao facto de todas as particularidades porque havia sido convidado por Bernardino para tomar parte no negócio e a este foi mister, para combater objeções, expor à aquele o plano e sua exequibilidade. O convite foi feito na própria fazenda da Lagoinha onde o dito fazendeiro tinha ido no intuito de comprar escravos, que Bernardino tinha então para vender ali. Quando Bernardino falou no subterrâneo, passou imediatamente a conduzir o dito fazendeiro para o lugar indicado a fim de lhe mostrar e convencêlo da dificuldade que há em descobrir tal esconderijo, não se estando previamente informado de sua situação e do modo de penetrar nele. Conduzi-o, pois, o dito fazendeiro para o interior de uma casa térrea, residência habitual dos donos ou administradores da fazenda, apesar de existirem nela edifícios de sobrado; penetrando em um quarto situado a direita da sala de jantar, ali mostrou-lhe um grande armário encostado a parede, e cuja última prateleira inferior, sendo impelida para fora em forma de gaveta, devia, segundo afirmava Bernardino, descobrir os degraus por onde se penetra no subterrâneo; e de facto já se ia inclinando para abrir a dita gaveta ou alçapão, quando o mencionado fazendeiro, que, mal grado seu, e por mera condescendência tinha-o acompanhado até aquele lugar, declarou que estava satisfeito que era escusado abrir porque não penetraria de forma alguma naquele esconderijo.

Eis o que me informa o dito fazendeiro, e creio que suas palavras merecem todo o peso (...)". 35

Do ofício depreende-se que Bernardino Martins fazia da sua fazenda ponto de negócio de cativos. O fazendeiro informante do juiz para lá fora justamente comprar escravos que Bernardino "tinha então para vender ali". A Lagoinha nos anos do comércio clandestino de escravos era ponto conhecido de recepção e redistribuição de africanos novos, tanto que, segundo o fazendeiro-delator, Bernardino pretendia "vender a ele declarante a fazenda" "ainda [que] com prejuízo" por "não querer ficar exposto a suspeitas que a simples posse da fazenda faria recair sobre ele, pelo que estava dispostos a desfazer-se dela a todo custo ou a estabelecer nela uma colônia". ${ }^{36} \mathrm{~A}$ trajetória do lugar e do fazendeiro nos ilícitos negócios do comércio de gente livre fazia com que as suspeitas fossem realmente levadas à sério, e, por isso, investigadas.

A missiva revela ainda o interesse do Ministro Nabuco de Araújo na questão do subterrâneo, que, segundo o delator, havia sido construído pelo proprietário anterior à Bernardino - João Alves da Silva Porto - "próximo a praia" e onde "se poderia ocultar grande número de negros poucos minutos depois de um desembarque". Considerando o histórico da Lagoinha, e sua condição de fazenda-negreira, a mística em torno do subterrâneo não era tão surreal assim. Em sua defesa o comendador Bernardino requerera na Secretaria de Polícia da Corte, em 19 de janeiro de 1856 , 
a inspeção da fazenda para afastar quaisquer suspeitas em torno da existência do esconderijo e das picadas que levariam os africanos à serra acima. Arguto, Barbosa da Cunha, ao revés, via nessa atitude "segurança fictícia”, produzidora de falsas aparências. "Denegou”, por isso, a demanda pela inspeção em sua jurisdição, que só teria o objetivo de "expor o governo ao ridículo".

A estratégia do comendador não o livrou da prisão, onde passou nove longos dias. Barbosa da Cunha acreditava que o fazendeiro, que fazia às vezes de negreiro, "quis apalpar o terreno, mas acabara abandonando seu intento "por se não achar sócios e coadjuvação". Entre os fazendeiros convidados estavam "os dois irmãos Castros", um dos quais o delator do caso ao juiz, que sustentava seu desinteresse no negócio afirmando haver encomendado 250 colonos na Alemanha "que há um mês se acham distribuídos pelas suas fazendas". Efetivamente uma coisa não eliminava a outra, a exemplo do caso de Joaquim Breves, exímio negreiro que estabeleceu colonos açorianos em uma de suas fazendas em meados de 1850 (PESSOA, 2018a, p. 113-142). Não por acaso, Barbosa da Cunha duvidava muito que os irmãos Castros tivessem declinado do empreendimento negreiro por esse motivo.

Restituído a liberdade por falta de provas, a defesa do comendador o transformava em vítima de um complô articulado pelos delatores, concorrentes do tino empreendedor de seu cliente. A eloquência e a semelhança com argumentos da política brasileira de nosso tempo, vale a transcrição:

(...) restituído a liberdade, convencido de ter encontrado em $\mathrm{V}$. Ex. ${ }^{a}$ uma autoridade zelosa e mesmo ardente na repressão de tão grande crime, ao mesmo tempo tão forte quanto deve ser a autoridade pública para resistir dos delatores conhecidos ou ocultos que hoje exploram o ardor do Governo Imperial e o voto entusiástico da opinião do país pela repressão do tráfico como mais uma mina que se oferece agora, não já somente aos que fazem da delação um oficio e precisão de campo que percorram e no qual se arriscam e [afadiguem] para encarecer os prêmios de sua torpeza, mas a outra classe de delatores que se levanta hoje para explorar a mesma mina, e essa é a daqueles que na correria desenfreada de sua cobiça quando sonham encontram em algum homem empreendedor um comerciante honesto para qualquer empresa, encaram-o como um estorvo as suas fantasias de improvisada riqueza e sem escrúpulo acolhem presunçosos o expediente iniquo de apresentam os seus concorrentes como seus suspeitos de tráfico. Estes, Exmo. Sr., são os delatores ocultos, os fornecedores [ansiosíssimos] de esclarecimentos ao Governo e a imprensa, e são os mais perigosos, e contra os quais o suplicante a justiça pública e grandes interesses do país invocam a garantia da fortaleza das autoridades, que 0 suplicante tem sempre encontrado em V. Ex. ${ }^{a}$ (...)

Para conseguir este desenredo e poder o suplicante recorre aos tribunais contra esses especuladores, o suplicante julga de seu dever e interesse pedir a V. Ex. ${ }^{a}$ o exame de todas as circunstancias denunciadas ultimamente pelo Jornal do Comercio de nove do corrente $=\mathrm{E}$. R. Mercê $=$ Bernandino Martins Ferreira de Faria". ${ }^{37}$ 
Até onde sabemos, o caso de Bernardino foi um dos últimos inquéritos de suspeitas de desembarques de africanos no litoral de São Paulo. Na dimensão do Império, o último caso confirmado foi o do negreiro Mary Smith que arribou em São Matheus, extremo norte do Espírito Santo no início de 1856. A história da fazenda da Lagoinha e seu porão misterioso evoca nosso desconhecimento sobre os lugares especializados na recepção de milhares de seres humanos, convertidos à escravidão ilegal no território brasileiro.

\section{Arremate: sobre o que se quis ocultar}

No litoral norte de São Paulo, a exemplo de outras praias do sudeste cafeeiro, durante mais de vinte anos propriedades como a Lagoinha, as fazendas-sítios da Lagoa, Tabatinga, Sombrio, Calhetas e Perequê funcionaram nas sombras, ocultando o pecado original da formação do Estado brasileiro. Eram nesses espaços que o crime de reduzir pessoas livres ao cativeiro era arrematado em terras brasileiras. As estimativas falam em torno de 800 mil africanos desembarcados em lugares como os que vimos, bastante conhecidos das autoridades imperiais, mas ainda desconhecidos da historiografia, e, talvez, por isso, ausentes da memória nacional (MATTOS, 2013). A obra da elite imperial em ocultá-los foi bastante bem sucedida, e reverbera até hoje em nossa ignorância.

Espaços como aquelas fazendas nos lembram também que a expansão cafeeira, que alicerçou a construção do Estado brasileiro na primeira metade do oitocentos, esteve intimamente associada aos negócios piratas montados nas duas margens do atlântico para manter, na ilegalidade, o fluxo de africanos para o ainda jovem Império do Brasil. Vale lembrar que construção de estrutura traficante sustentou a economia cafeeira durante a montagem de seu complexo no Vale do Paraíba nas últimas duas décadas da primeira metade do oitocentos (PESSOA, 2018c; PEREIRA; PESSOA, 2019).

Conhecer melhor a trajetória de lugares como esses e de seus operadores é também o primeiro passo para nos reencontramos com um passado incômodo e doloroso, que se quis ocultar e esquecer, mas que temos o dever de relembrarmos. Provocá-los permite construirmos novas versões sobre uma das maiores tragédias da nossa formação como nação, resgatando responsabilidades históricas do silêncio construído pela elite pretérita do Brasil. 


\section{Referências}

AGOSTINI, C. Mundo atlântico e clandestinidade: dinâmica material e simbólica em uma fazenda litorânea do Sudeste, século XIX. Tese (Doutorado em História) - Instituto de Ciências Humanas e Filosofia, Universidade Federal Fluminense, Niterói, 2011.

ALVES, L. B. A diáspora africana no litoral norte-paulista: desafios e possibilidades de uma abordagem arqueológica. Dissertação (Mestrado em Arqueologia) - Museu de Arqueologia e Etnologia, Universidade de São Paulo, São Paulo, 2016.

BETHELL, L. A abolição do comércio brasileiro de escravos: a Grã-Bretanha, o Brasil, e a questão do comércio de escravos (1807-1869). Brasília, DF: Senado Federal, 2002.

CAPELA, J. Conde de Ferreira \& C. ${ }^{a}$. Traficantes de Escravos. Lisboa: Edições Afrontamento, 2012.

CARVALHO, M.J.M de. O desembarque nas praias: o funcionamento do tráfico de escravos depois de 1831. Revista de História, São Paulo, n. 167, p. 223-260, 2012.

CHALHOUB, Sidney. A força da escravidão: ilegalidade e costume no Brasil oitocentista. São Paulo: Companhia das Letras, 2012.

DEAN, W. Rio Claro: um sistema brasileiro de grande lavoura (1820-1920). Rio de Janeiro: Paz e Terra, 1977.

FERREIRA, R. História sobre o infame negócio de africanos da África Oriental e Ocidental, com todas as ocorrências desde 1831 a 1853. Estudos Afro-Asiáticos, Rio de Janeiro, n. 28, p. 219-229, 1995.

FERREIRA, R. Dos Sertões ao Atlântico: tráfico ilegal de escravos e comércio lícito em Angola, 1830-1860. Luanda: Editora Kilombelombe, 2012.

GUISARD FILHO, F. Taubaté: Atas da Câmara. São Paulo: Empresa Editora Universal, 1943-1944. 10 volumes.

GUISARD FILHO, F. Ubatuba. Achegas à história do litoral paulista. São Paulo: Graça Paulista, 1940, v. 1.

MAMIGONIAN, B. O Estado nacional e a instabilidade da propriedade escrava: a lei de 1831 e a matrícula dos escravos de 1872. Almanack, Guarulhos, n. 2, p. 20-37, 2011.

MAMIGONIAN, B. Africanos livres: a abolição do tráfico de escravos no Brasil. São Paulo: Companhia das Letras, 2017.

MARCÍLIO, M. L. Caiçara, terra e população: estudo de demografia histórica e da história social de Ubatuba. São Paulo: Paulinas, 1986.

MATTOS, Hebe. Diáspora negra e lugares de memória: a história oculta das propriedades voltadas para o tráfico clandestino de escravos no Brasil imperial. Niterói: EDUFF, 2013. 
MOTTA, J. F. Corpos escravos, vontades livres: posse de cativos e família escrava em Bananal (1801-1829). São Paulo: Annablume, 1999.

MORENO, B. Demografia e trabalho escarvo nas propriedades escravas de Bananal, 1830-60. Dissertação (Mestrado em História) - Faculdade de Filosofia, Letras e Ciências Humanas, Universidade de São Paulo, São Paulo, 2013.

PARRON, T. A política da escravidão no Império do Brasil, 1826-1865. Rio de Janeiro: Civilização Brasileira, 2011.

PEREIRA, Walter Luiz Carneiro de Mattos; PESSOA, Thiago Campos. Silêncios Atlânticos: sujeitos e lugares praieiros no tráfico ilegal de africanos para o sudeste brasileiro (c.1830- c.1860). Estudos Históricos, Rio de Janeiro, v. 32, n. 66, p. 79-100, 2019.

PEREIRA, Walter Luiz Carneiro de Mattos. A trama da ilegalidade: tráfico de africanos no Sudeste brasileiro (1850-1860); In: XAVIER, Regina Célia Lima; OSÓRIO, Helen (orgs.). Do tráfico ao pós-abolição: trabalho compulsório e livre e a luta por direitos sociais no Brasil. São Leopoldo: Oikos, 2018.

PEREIRA, Walter Luiz Carneiro de Mattos. José Gonçalves da Silva: tráfico e traficante de escravos no litoral norte fluminense, depois da lei de 1850. Tempo, Niterói, n. 31, p. 285-312, 2011.

PESSOA, Thiago Campos. O império da escravidão: o complexo Breves no vale do café (Rio de Janeiro, c.1850-c.1888). Rio de Janeiro: Arquivo Nacional, 2018a.

PESSOA, Thiago Campos. A "delação alcoforado" e o comércio ilegal de africanos: notas de pesquisa. In: OSÓRIO, Helen; XAVIER, Regina. Do tráfico ao pós-abolição: trabalho compulsório e livre e a luta por direitos sociais no Brasil. São Leopoldo: Oikos, 2018b. p. 165-206.

PESSOA, Thiago Campos. Sob o signo da ilegalidade: o tráfico de africanos na montagem do complexo cafeeiro (Rio de Janeiro, 1831-1850). Tempo, Niterói, v.24, n. 3, p. 422-449, 2018c.

REDIKER, M. O Navio Negreiro: uma história humana. São Paulo: Companhia das Letras, 2011.

RODRIGUES, J. De Costa a Costa: escravos, marinheiros e intermediários no tráfico negreiro de Angola para o Rio de Janeiro. São Paulo: Companhia das Letras, 2005.

SLENES, R. Na senzala uma flor: esperanças e recordações na formação da família escrava - Brasil, Sudeste - século XIX. Rio de Janeiro: Nova Fronteira, 1999.

VIDAL, L. A gênese dos pousos no Brasil moderno. Considerações sobre as formas (urbanas) nascidas da espera. Tempo, v. 22, n. 40, p. 400-419, 2016. 


\section{Notas}

${ }^{1} \mathrm{O}$ autor agradece a leitura atenta e as críticas valiosas de Camilla Agostini, professora do Departamento de Arqueologia da UERJ.

${ }^{2}$ Segundo Voyages, dos 432.953 africanos embarcados em África, 383.728 desembarcaram no sudeste brasileiro em 888 viagens entre 1831 e 1856.

${ }^{3}$ Arquivo Público do Estado de São Paulo (APESP). Juízes de Direito - São Sebastião (1833-1891). C04815. Ofício de Francisco Lourenço a José Antônio Pimenta Bueno, 06 de agosto de 1833.

${ }^{4}$ APESP. Juízes de Direito - São Sebastião (1833-1891). C04815. Ofício de Francisco Lourenço a Presidência da Província. Caraguatatuba, 06 de julho de 1833.

${ }^{5}$ APESP. Juízes de Direito - São Sebastião (1833-1891). C04815. São Sebastião, 03 de abril de 1834.

${ }^{6}$ APESP. Ofícios dos juízes de direito, de paz e municipal de Santos para o Presidente de Província (1833-1837). C4806, cx. 61, ordem, 4806. Pimenta Bueno para PP, 09/05/1834.

${ }^{7} \mathrm{~A}$ historiografia atrelada à proibição do comércio negreiro, desloca para o final da década de 1830 o recrudescimento do tráfico negreiro, sobretudo, após o Regresso Conservador. Ao que parece, na área economicamente mais importante do Império, esse processo começou no início da década. Ainda que tivesse se tornado política de Estado só no final dos anos de 1830, já era a realidade de boa parte dos municípios litorâneos do vale do café.

${ }^{8}$ APESP. Juízes de Direito - São Sebastião (1833-1891). C04815. São Sebastião, 03/04/1834

${ }^{9}$ APESP. Ofícios dos juízes de direito, de paz e municipal de Santos para o Presidente de Província (1833-1837). C4806, cx. 61, ordem, 4806. Ofício de Pimenta Bueno ao Presidente da Província de São Paulo, 09 de maio de 1834.

${ }^{10}$ APESP. Ofícios dos juízes de direito, de paz e municipal de Santos para o Presidente de Província (1833-1837). C4806, cx. 61, ordem, 4806. Ofício n. 35, sem data.

11 Tratam-se do Patacho Liberal, Bergantim Príncipe Augusto, Brigue-Escuna Caridade e Barca Comodore. APESP. Ofícios dos juízes de direito, de paz e municipal de Santos para o Presidente de Província (1833-1837). C4806, cx. 61, ordem, 4806. Relação incluída ao aviso do min. Antônio Paulino Limpo de Abreu ao Presidente da Província de São Paulo, 12 de agosto de 1837.

${ }^{12}$ Ofício de Joaquim Firmino Peixoto Jorge ao Brigadeiro Bernardo José Pinto Gavião Peixoto, presidente da província de São Paulo. Santos, 14 de setembro de 1837.

${ }^{13}$ APESP. Juízes de Direito - São Sebastião (1833-1891). C04815. São Sebastião, 20/03/1834.

${ }^{14}$ APESP. Ofícios dos juízes de direito, de paz e municipal de Santos para o Presidente de Província (1833-1837). C4806, cx. 61, ordem, 4806. Ofício de Manoel Antonio da Silva, Juiz de Paz da Vila de São Sebastião, 17/04/1834 APESP. Ofícios dos juízes de direito, de paz e municipal de Santos para o Presidente de Província (1833-1837). C4806, cx. 61, ordem, 4806. Ofício de Manoel Antonio da Silva, Juiz de Paz da Vila de São Sebastião, 17/04/1834

${ }^{15}$ APESP. Ofícios dos juízes de direito, de paz e municipal de Santos para o Presidente de Província (1833-1837). C4806, cx. 61, ordem, 4806. Carta de Anastácio José Ribeiro a José Bernardino de Sá, 12 de Abril de 1834.

${ }^{16}$ APESP. Ofícios dos juízes de direito, de paz e municipal de Santos para o Presidente de Província (1833-1837). C4806, cx. 61, ordem, 4806. Ofício de Pimenta Bueno ao Presidente da Província de São Paulo, 09 de maio de 1834. 
${ }^{17}$ Hoje o rio Tabatinga divide os municípios de Ubatuba e Caraguatatuba, distando cerca $37 \mathrm{~km}$ daquele município e $17 \mathrm{~km}$ deste.

${ }^{18}$ APESP. Secretaria de Governo - Ofícios do Juiz de Direito de Santos para o Governo da Província. C04807. Pasta 06, 1841. Cópia autenticada por pública forma de uma mandado de auto de diligência comandada por Antônio Egídio da Cunha, 28 de Janeiro de 1841.

${ }^{19}$ APESP. Secretaria de Governo - Ofícios do Juiz de Direito de Santos para o Governo da Província. C04807. Pasta 06, 1841. Autos de processo informatório conduzido por Antônio Egídio da Cunha, Ubatuba, 23 de dezembro de 1840.

${ }^{20}$ APESP. Secretaria de Governo - Ofícios do Juiz de Direito de Santos para o Governo da Província. C04807. Pasta 06, 1841. Conclusão e publicação de sentença, Ubatuba, 23 de dezembro de 1840.

${ }^{21}$ APESP. Secretaria de Governo - Ofícios do Juiz de Direito de Santos para o Governo da Província. C04807. Pasta 06, 1841. Paço da Câmara da Vila de Ubatuba a Presidência da Província de São Paulo. Sessão extraordinária de 15 de fevereiro de 1841.

${ }^{22}$ Vale notar que Pereira Jorge desembarcara no Sombrio exatamente no mesmo dia em que Bernardo Nascente de Azambuja - chefe de polícia no Rio de Janeiro - devassara a fazenda da Marambaia em Mangaratiba, fato que indica claramente uma ação deliberada e orquestrada pelo aviso do Ministério de 16 de Janeiro de 1851 sob os principais portos clandestinos do sudeste.

${ }^{23}$ Arquivo Nacional (AN). Auto de busca e apreensão das fazendas Sombrio, Calheras e Figueira. 01 de fevereiro de 1851. Série Justiça. IJ1 894.

${ }^{24}$ AN. Ofício de Joaquim Firmino Pereira Jorge a Presidência da Província de São Paulo. 12 de fevereiro de 1851. Série Justiça. IJ1 894

${ }^{25} \mathrm{AN}$. Auto de busca e apreensão da fazenda de Perequê,11 de fevereiro de 1851. Série Justiça. IJ1 894.

${ }^{26}$ AN. Ofício da Presidência da Província ao Ministério da Justiça, 08 de abril de 1851. Série Justiça IJ1 894

${ }^{27}$ AN. Ofício do juiz municipal dos termos de São Sebastião e Vila Bela da Princesa. 17 de fevereiro de 1852. Série Justiça. IJ6 470

${ }^{28}$ AN. Ofício da Presidência da Província ao Ministério da Justiça, 10 de outubro de 1851. Série Justiça. IJ 893

${ }^{29}$ AN. Ofício do delegado de polícia de São Sebastião - José Antonio da Silva - à Presidência da Província, 23 de agosto de 1851. Série Justiça, IJ1 895 (1854-56).

${ }^{30}$ AN. Ofício do delegado de polícia de Ubatuba - Antonio Barbosa da Cunha - à Presidência da Província, 20 de agosto de 1851. Série Justiça, IJ1 895 (1854-56).

${ }^{31}$ AN. Ofícios de Eusébio de Queiroz a Manuel Vieira da Costa, 06 e 09 de agosto de 1851. Série Justiça. IJ6 470

${ }^{32}$ AN. Ofício da Presidência da Província de São Paulo ao Ministério da Justiça, 23 de abril de 1856. Série Justiça, IJ1 895 (1854-56).

${ }^{33}$ APESP. Ofício da Presidência da Província de São Paulo ao Ministério da Justiça, 27 de dezembro de 1584. C05535

${ }^{34}$ Biblioteca Nacional. Jornal do Commercio, 9 de janeiro de 1856. 
${ }^{35}$ AN. Ofício de Antônio Barbosa da Cunha - Juiz Municipal de Ubatuba - ao Conselheiro Nabuco

- Ministro da Justiça. Ubatuba, 7 de fevereiro de 1856. Série Justiça, IJ6 522

${ }^{36}$ AN. Ofício de Antônio Barbosa da Cunha - Juiz Municipal de Ubatuba - ao Conselheiro Nabuco - Ministro da Justiça. Ubatuba, 14 de janeiro de 1856. Série Justiça, IJ6 522

${ }^{37}$ AN. Carta de Bernandino Martins Ferreira de Faria escrita entre o final de janeiro e início de fevereiro de 1856. Série Justiça, IJ6 522

\section{DECLARAÇÃO DE FINANCIAMENTO}

Pesquisa financiada pela FAPERJ por bolsa de pós-doutorado (processo E/26/202.074/2015) e pelo Edital Universal do CNPq (processo 436140/2018-7).

Thiago Campos PESSOA. Doutor em História Social pela Universidade Federal Fluminense. Pesquisador associado ao Laboratório de História Oral e Imagem (UFF/UFJF) e ao grupo de pesquisa interinstitucional O Império do Brasil e a Segunda Escravidão. Autor de O Império da Escravidão: o complexo Breves no Vale do café (Rio de Janeiro, c.1850 - c.1888), livro premiado pelo Arquivo Nacional (2015), pelo Arquivo Público do Estado do Rio de Janeiro (2015) e pelo Prêmio UFF de Teses e Dissertações (2016). Atua no ensino e pesquisa em história do Brasil, com ênfase no período imperial e na história da escravidão. 